\title{
Benefits derived from use of social media by researchers for agricultural information in Ibadan Metropolis, Oyo State.
}

\author{
Kareem, A.T ${ }^{1}$, ,Olayemi, $_{\text {O.O }}{ }^{1}$, Babatunde, R.O $^{1}$., Ajanaku, O.A ${ }^{1}$., Alarape, A.B ${ }^{1}$., Odewale, M.O ${ }^{2}$ \\ ${ }^{1}$ Federal College of Forestry, Ibadan, Oyo State. P.M.B.5087 Jericho Ibadan \\ ${ }^{2}$ Forestry Research Institute of Nigeria, P.M.B. 5054 Jericho Ibadan. \\ *Correspondence: bodecrespo1@yahoo.co.uk +2348054035443
}

DOI: $10.31364 / \mathrm{SCIRJ} / \mathrm{v} 8.18 .2020 . P 0820792$

http://dx.doi.org/10.31364/SCIRJ/v8.i8.2020.P0820792

\begin{abstract}
This study investigated benefits derived from use of social media by researchers for agricultural information in Ibadan Metropolis, Oyo State. Random sampling techniques were used through questionnaire to collect information from 112 researchers. Data were analyzed using descriptive statistics of frequency counts, percentage, mean and Pearson Product Moment Correlation $(P P M C)$ at $0.05 \%$ level of significance. Results of analysis revealed that majority of the respondents were male and are of middle age, many have B.Sc. while few had M.Sc. with most of them married, and 6-10years of experience as researchers. The result further reveals that larger percentage of the respondent $75.9 \%$ and $82.1 \%$ regularly makes use of Facebook and WhatsApp respectively. The result showed that benefits derived from use of social media has high percentage of the respondent and also encourages them to reach out to their colleagues across their organization, helps to connect peers with similar research interest leading to collaboration on new projects, promotes the flow of communication and desire to share knowledge with others and the role of social media to establish connections, create awareness and promote individual or organizational project or research reports and feedback. The result further shows that there are some constraints faced through the usage of social media as agreed with by the respondent that one of the major constraint is Network congestion as well as irregular power supply. The result also revealed that there is no significant relationship between benefits derived from the respondents $(r=0.044, p>0.05)$ and use of social media. This implies that benefit derived from the use of social media for research work is similar or not different from the benefit derived from the individual who uses social medial for fun. It is therefore recommend that every agricultural researcher should subscribe to and maintains multiple accounts social media and also encouraged to used social media network and collaborate with colleagues institutes different from their own. Agricultural researchers should used social media to get mentors and mentees in order to keep their profession alive.
\end{abstract}

\section{Keywords: Benefits derived, Researcher, Use, Social media, Agricultural information}

\section{Introduction}

In every human society, communication is important because it means through which man interacts and makes meaningful relationships. Hence, communication among professional groups, friends and associates gives room for people to define their collective interest, identities and common goals. The longman dictionary of cotemporary English defines the word "connect" as joined together. It is a known fact that if two people or events are joined together they will definitely affect each other- no wonder the adage "two heads are better than one".

Individuals are professionals across disciplines therefore establish connections with one another for diverse reasons. These reasons include avoidance of loneliness, exchange of ideas, or information mentoring and career development. The connection formed between two or more people is often referred to as networking, while the group formed is a network. With the introduction of 
information technologies, networking among different groups has been made easier through internet connectivity and this is being exploited by people in every walk of life, including agriculture.

[2] Observe that communication linkage of research reports in Ngeria is the top-down linkage connections of passing down research reports to the farm families at different local areas through extensions, with distance as major hindrance. It is very important that researches get connected on professional and interpersonal relational levels to channel the course for fast information release to assist in the sharing of knowledge of research reports despite distance and efforts.

Corrobating this assertion, [3] Observes that agricultural research linkages open up researchers annually through representations to participate in discussing national problems, a channel that is less effective to research growth and development. This suggests that despite the wealth of agricultural research churned out from research institutions, there is challenge of prompt availability, awareness and full use of professional research reports, prompt connection and networking with a wider medium to capture a larger audience among agricultural researchers. To establish such professional connections, different e-media channels will be effective as possible opportunities for electronic networking. These include e- mail, twitter, blogs, My space, LinkedIn, Flickr among others. All these are classified as social media which individuals and institutions can connect with to effectively boost research.

Just as much as its variety of definitions, social media includes a diversity of applications with different core functions and structures. The most popular and high profile social media, Social Network Sites (SNSs), allows people to create their own Web pages and then share contents and communicate with online friends [10]. Unlike other social media, SNSs let users articulate their social networks by providing visible lists as well as traversing them easily [4]. Hence, rather than expanding networks to new people, offline acquaintances are the primary communication groups within SNSs and the main activities are based on relationship management. Best examples of SNSs are Facebook, MySpace, Bebo, and Linked In.

While sharing SNSs' traits of requiring registration to obtain a personal home page and connect with friends, content communities focus on sharing a certain type of content, such as photo, video, music, and bookmark, also contents are easily shared by a networked group with a tag to the content [10]. Social media is a generic term covering different online platforms with various attributes, communication formats, and sociability function, there are certain characteristics that all social media applications fundamentally share. [10]identified five specific characteristics that underline the operations of all social media: participation, openness, conversation, community, and connectedness. As social media begins to draw attention from both academy and business practices, scholars have begun to explore the characteristics of social media users and motives of new media use. In general, it was found that young people have been in the front line in creating and sharing content in new media [11][12]. As social media continues to evolve, the pattern of social media use is also changing. It is against this background that the study therefore investigates benefits derived from use of social media by researchers for agricultural information in Ibadan Metropolis, Oyo State. The specific objectives are to:

1. Examine the socio-economic characteristics of the researchers

2. Identify the social media used by researchers

3. Identify the benefits derived from the use of social media

4. Identify the constraints in the use of social media by researchers. 


\section{Hypothesis of the study}

The hypothesis stated in the null form is tested:

Ho1: There is no significant relationship between benefits derived and use of social media

\section{Materials and Methods}

The study was carried out in Research institutes within Ibadan metropolis, Oyo state Nigeria. Ibadan consist of eleven (11) local government Areas. Ibadan is the capital of Oyo state and it is also the largest metropolitan geographical area. Ibadan is located in south western Nigeria in the South-eastern part of Oyo state about 120km east of the border with the Republic of Benin in the forest zone close to the boundary between the forest and the savanna. The city ranges elevation from $150 \mathrm{~m}$ in the valley area, to $275 \mathrm{~m}$ above sea level on the major North-South ridge which crosses the central part of the city. The city's total area is $1,190 \mathrm{sq}$ miter $\left(3,080 \mathrm{~km}^{2}\right)$. The city is naturally drained by four rivers with many tributaries: Ona Rivers in the North and West; Ogberi Rivers towards the East; Ogunpa Rivers flowing through the city and kudeti Rivers in the central part of the metropolis, Ogunpa Rivers, a third-order stream with a channel length of $12.76 \mathrm{~km}$ and a catchment area of $54.92 \mathrm{~km}^{2}$. the climate is equatorial, notably with dry and wet season with relatively high humidity. The dry season last from November-March while the wet season starts from April and ends in October. Average daily temperature ranges between $25^{\circ} \mathrm{C}\left(77.0^{\circ} \mathrm{F}\right)$ and $35^{\circ} \mathrm{C}\left(95.0^{\circ} \mathrm{F}\right)$, almost throughout the year and on latitude $7^{0} \mathrm{~W}$ and longitude $9^{0} \mathrm{E}$ of the equator and longitude $3^{0} \mathrm{~W}$ and $5^{0} \mathrm{~S}$ of theGreenwich Meridian [9]. Random sampling techniques were used to carry out this study. Out of eight (8) Research Institutes in Ibadan which are: International Institute of Tropical Agriculture (IITA), Forestry Research Institute of Nigeria (FRIN), Cocoa Research Institute of Nigeria (CRIN), Institute of Agricultural Research and Training (IART), National Horticultural Research Institute (NIHORT), National Cereals Research Institute (NCRI), National Animal Production Research Institute (NAPRI), and Nigerian Institute of Social and Economic Research (NISER).Three (3) Agricultural Research Institutes was randomly selected which are;National Horticultural Research Institute (NIHORT), Forestry Research Institute of Nigeria (FRIN), and Institute of Agricultural Research and Training (IART). Then, 30\% of the total population of the researchers was randomly selected from each of the Research Institutes. A total number of 112 questionnaires were administered which represent respondents that was used for the study. Descriptive statistics such as frequency distribution, percentages were used to analyze all the objectives and PPMC for hypothesis.

\section{Results and Discussion}

\section{Socio-economic characteristics of respondents}

The result in table 1 shows that $66.1 \%$ of the respondents were between the age of 21 -40years, $30.4 \%$ of them falls within the age category of 41-60years, 60years and above took $3.6 \%$ of the total population. This result corresponds with [1] who found that population between 21-40years of age constitute the active work force. In gender distribution of the respondents, the result reveals that $55.4 \%$ of the respondents are male and $44.6 \%$ of the respondents were female. This means that researchers in all the research institutes used were of males than females. This is in line with [14] who stated that agriculture is generally regarded in Africa as an occupation for men. Also in line with [12] reported that boys use SNSs to expand their networks by making new friends Also in tandem with [13] also found similar results that males are more likely to use SNSs with the purpose of flirting and learning about events. The result also shows that $75.0 \%$ of the respondents were married, $19.6 \%$ were single, $4.5 \%$ were Divorced and $0.9 \%$ are widow. This indicates that most of the respondents were married which implies that they are matured and responsible, this is in line with the findings of [1] who stated that marriage confers responsibility.The table further reveals that most of the respondents have 
Bsc. i.e 41.1\%, 37.5\% have Msc. $17.0 \%$ have HND, 2.7\% have ND and 1.8\% has PhD. This implies that Bsc is entry requirements for researchers and majority falls within are yet to have additional qualification. [8]asserted that education is required as a basic prerequisite to sharpen extension agents' knowledge, skills and practices for effective delivery if food security will be achieved in Nigeria. The result also indicates that informs of experience, majority $45.5 \%$ of the respondents falls between $6-10 y e a r s, 28.6 \%$ of them fall within $1-5 y$ years, $16.1 \%$ have $11-15$ years, $5.4 \%$ have $16-20 y e a r s$, while $4.5 \%$ have above 20 years of experience.

Table 1: Socio-economic characteristics of respondents

\begin{tabular}{|c|c|c|}
\hline Variables & Frequency & Percentage \\
\hline \multicolumn{3}{|l|}{ Age } \\
\hline 21-40years & 74 & 66.1 \\
\hline 41-60years & 34 & 30.4 \\
\hline Above 60years & 4 & 3.6 \\
\hline \multicolumn{3}{|l|}{ Gender } \\
\hline Male & 62 & 55.4 \\
\hline Female & 50 & 44.6 \\
\hline \multicolumn{3}{|l|}{ Marital status } \\
\hline Single & 22 & 19.6 \\
\hline Married & 84 & 75.0 \\
\hline Divorced & 5 & 4.5 \\
\hline Widow & 1 & 0.9 \\
\hline \multicolumn{3}{|c|}{ Level of education } \\
\hline ND & 3 & 2.7 \\
\hline HND & 19 & 17.0 \\
\hline Bsc. & 46 & 41.1 \\
\hline Msc & 42 & 37.5 \\
\hline $\mathrm{PhD}$. & 2 & 1.8 \\
\hline \multicolumn{3}{|c|}{ Years of experience } \\
\hline $1-5$ years & 32 & 28.6 \\
\hline 6-10years & 51 & 45.5 \\
\hline 11-15years & 18 & 16.1 \\
\hline 16-20years & 5 & 4.5 \\
\hline Above 20years & 6 & 5.4 \\
\hline Total & 112 & 100.0 \\
\hline
\end{tabular}




\section{Social media use by Researchers}

The result in table 2 reveals that WhatsApp was regularly (82.1\%) used as social media among the researchers, followed by Facebook (75.9\%), YouTube was occasionally (50.9\%) used, followed by Imo (46.4\%), while MSN (49.1) was never used among agricultural researchers. This implies that WhatsApp is the most popular social media platform used among agricultural researchers in the study area compared to [5] who reveals that Facebook is the most popular used social media in the world. However, agricultural researchers should be encouraged to open multiple accounts on the various social networking sites so that they can collaborate and network with a larger audience of like minds.

Table 2: Social media use by Researchers

\begin{tabular}{llll}
\hline Social media & Regularly & Occasionally & Never \\
\hline Facebook & $85(75.9)$ & $25(22.3)$ & $2(1.8)$ \\
WhatsApp & $92(82.1)$ & $15(22.3)$ & $5(4.5)$ \\
Twitter & $34(30.4)$ & $48(42.9)$ & $30(26.8)$ \\
YouTube & $28(25.0)$ & $57(50.9)$ & $27(24.1)$ \\
BBM & $22(19.6)$ & $48(42.9)$ & $42(37.5)$ \\
Yahoo Messenger & $37(33.0)$ & $41(36.6)$ & $34(30.4)$ \\
MSN & $14(12.5)$ & $43(38.4)$ & $55(49.1)$ \\
Google talk & $26(23.2)$ & $38(33.9)$ & $48(42.9)$ \\
Conference call & $29(25.9)$ & $44(39.3)$ & $39(34.8)$ \\
Instagram & $36(32.1)$ & $46(41.1)$ & $30(26.8)$ \\
Imo & $26(23.2)$ & $52(46.4)$ & $34(30.4)$ \\
Google plus & $23(20.5)$ & $40(35.7)$ & $49(43.8)$ \\
Snapchat & $15(13.4)$ & $46(41.1)$ & $51(45.5)$ \\
LinkedIn & $18(16.1)$ & $42(37.5)$ & $52(46.4)$ \\
\hline
\end{tabular}

Percentage (\%) in parenthesis

\section{Categorization of respondents based on their level in the use of social media}

The result in table 3 shows the level of categorization that $50.9 \%$ of the respondents were low on the use of social media, while $49.1 \%$ of the respondents were high on the use of social media in the study area. The implication is that the levels at which researchers are using social media for Agricultural information is low while at high level for other activities.

TABLE 3: Categorization of respondents based on their level in the use of social media

\begin{tabular}{lll}
\hline Variable & Frequency f & Percentage \% \\
\hline High & 55 & 49.1 \\
Low & 57 & 50.9 \\
Total & $\mathbf{1 1 2}$ & $\mathbf{1 0 0 . 0}$ \\
\hline
\end{tabular}

Above mean value=High, below mean value $=$ Low $($ Mean= 13.89) 


\section{Benefit derived from using social media}

The table 4 reveals that many of the respondents benefits from social media. Major (78.6\%) of the respondents indicated that social media encourage them to reach out to colleagues across their organization, $44.6 \%$ are of the opinion that social media makes them smarter. This confirms [7] view that social media network services focus on building online communities of people who share the same interests or activities. However, researchers should be encouraged more on using social media to communicate their research result because this will give more mileage whilst supporting democratization of knowledge and information [6].

Table 4.: Benefit derived from using social media

\begin{tabular}{|c|c|c|c|}
\hline Benefit statements & High & Moderate & Low \\
\hline $\begin{array}{l}\text { It encourage you to reach out to colleagues across your } \\
\text { organization }\end{array}$ & $88(78.6)$ & $24(21.4)$ & - \\
\hline Trying to keep you motivated and engaged & $59(52.7)$ & $47(42.0)$ & $6(5.4)$ \\
\hline Social media makes you smarter & $46(41.1)$ & $50(44.6)$ & $16(14.3)$ \\
\hline $\begin{array}{l}\text { The learning opportunities you can offer with social media are } \\
\text { endless }\end{array}$ & $64(57.1)$ & $36(32.1)$ & $12(10.7)$ \\
\hline $\begin{array}{l}\text { Connecting with peers who share similar research interests can } \\
\text { lead to collaboration on new and exciting project }\end{array}$ & $75(67.0)$ & $30(26.8)$ & $7(6.3)$ \\
\hline It provides good source of information & $78(69.6)$ & $29(25.9)$ & $5(4.5)$ \\
\hline $\begin{array}{l}\text { You can pass information to other researchers in different } \\
\text { Institutes within a short period through social media. }\end{array}$ & $86(76.8)$ & $23(20.5)$ & $3(2.7)$ \\
\hline Fast flow of communication & $77(68.8)$ & $30(26.8)$ & $5(4.5)$ \\
\hline Desire to share knowledge with others & $68(60.7)$ & $40(35.7)$ & $4(3.6)$ \\
\hline Experience of using online discussion tools & $64(57.1)$ & $41(36.6)$ & $7(6.3)$ \\
\hline $\begin{array}{l}\text { Increase in reading and writing skills to communicate with } \\
\text { others easily. }\end{array}$ & $65(58.0)$ & $41(36.6)$ & $6(5.4)$ \\
\hline Posting and evaluating contents freely on social media. & $68(60.7)$ & $35(31.3)$ & $9(8.0)$ \\
\hline $\begin{array}{l}\text { It enables you to ask questions or start a conversation around a } \\
\text { particular topic. }\end{array}$ & $74(66.1)$ & $30(26.8)$ & $8(7.1)$ \\
\hline
\end{tabular}

Percentage \% in Parenthesis

\section{Categorization of respondents based on their level of benefit}

The table 5 based on the level of categorization shows that $50.0 \%$ of the respondents had a high benefit on the use of social media, while $50.0 \%$ of the respondents were low to social media.

Table 5: Categorization of respondents based on their level of benefit

\begin{tabular}{lcc}
\hline Variable & Frequency (f) & Percentage (\%) \\
\hline High & 56 & 50.0 \\
Low & 56 & 50.0 \\
Total & 112 & 100.0 \\
\hline
\end{tabular}

Above mean value=High, below mean value=Low $($ Mean $=33.36)$ 


\section{Constraints faced in the use of social media}

The table above reveals that major constraints $(68.8 \%)$ of the respondents is Network congestion, minor constraints $(53.6 \%)$ are ability to effectively use the computer and phones, and compliance concerns while not a constraints (57.1\%) is too old for social media. This shows that Network congestion is the most problem faced when they are using social media.

Table 6: Constraints faced in the use of social media

\begin{tabular}{llll}
\hline Constraints & $\begin{array}{l}\text { Major } \\
\text { Constraints }\end{array}$ & $\begin{array}{l}\text { Minor } \\
\text { Constraints }\end{array}$ & $\begin{array}{l}\text { Not } \\
\text { Constraints }\end{array}$ \\
\hline Network Congestion & $77(68.8)$ & $32(28.6)$ & $3(2.7)$ \\
Cost of data & $55(49.1)$ & $51(45.5)$ & $6(5.4)$ \\
Irregular power supply & $54(48.2)$ & $49(43.8)$ & $9(8.0)$ \\
Ability to effectively use the computer and phones & $23(20.5)$ & $60(53.6)$ & $29(25.9)$ \\
Inadequate knowledge on the use of social media & $22(19.6)$ & $46(41.1)$ & $44(39.3)$ \\
Wrong time in the use of social media & $31(27.7)$ & $44(39.3)$ & $37(33.0)$ \\
Unsure on what to write about & $21(18.8)$ & $40(35.7)$ & $51(45.5)$ \\
Compliance concerns & $19(17.0)$ & $60(53.6)$ & $33(29.5)$ \\
Inadequate of control over what happens & $21(18.8)$ & $54(48.2)$ & $37(33.0)$ \\
You haven't defined how social media fits into your research & $17(15.2)$ & $50(44.6)$ & $45(40.2)$ \\
strategy & & & \\
Too old for social media & $12(10.7)$ & $36(32.1)$ & $64(57.1)$ \\
Virus interruption & $29(25.9)$ & $45(40.2)$ & $38(33.9)$ \\
\hline Perat & & &
\end{tabular}

Percentage \% in Parenthesis

Table 7: PPMC Analysis of Benefit derived from the use of Social Media.

\begin{tabular}{llll}
\hline Variable & r-value & p-value & Decision \\
\hline Benefit derived and & 0.044 & 0.645 & NS \\
Use of social media & & & \\
\hline NS= Not significant at 0.05 & & &
\end{tabular}

NS= Not significant at 0.05

The result in table 7 shows that there is no significant relationship between benefits derived from the respondents $(r=0.044, p>0.05)$ and use of social media. This implies that benefit derived from the use of social media for research work is similar or not different from the benefit derived from the individual who uses social medial for fun. Therefore, null hypothesis is accepted and the alternative hypothesis is rejected.

\section{Conclusion and Recommendations}

This study revealed that majority of the respondents were male and are of middle age, many have Bsc while few had Msc with most of them married, and 6-10years of experience as researchers. The result further reveals that larger percentage of the respondent $75.9 \%$ and $82.1 \%$ regularly makes use of Facebook and Whatsapp respectively.The findings also stated that for the benefits derived from use of social media, high percentage of the respondent stated that it encourages them to reach out to their colleagues across their organization. It also helps to connect peers with similar research interest leading to collaboration on new projects. The effect of social media was clearly stated as show from this research such that it promotes the flow of communication and desire to share knowledge 
with others. The role of social media is to establish connections, create awareness and promote individual or organizational project or research reports and feedback. Social media help to create the kind of researchers' environment that pulls knowledge and expertise together, thereby contributing knowledge and experience to establish network. Social media also help researchers to establish reputation as experts or consultants on research report. Their usage among researchers is reported to be on the increase, hence, agricultural researchers should increase their participation to connect, network and communicate agricultural research prompt on social networking sites. This research work further shows that there are some constraints faced through the usage of social media as agreed with by the respondent that one of the major constraints is Network congestion as well as irregular power supply.It can be concluded that with the use of social media researchers can get information needed and gain experience from colleagues, peers and also add to their skills and knowledge in their area of specialization. Researchers can also share the result of their findings through the use of social media.

\section{References}

1. Akinbile, L.A (2007). Social Impact of limestone Exploitation in Yewa North Local Government Area of Ogun State, Nigeria.Pakistan Journal of Social Science1:107 111, Maxwell Journal.

2. Agbamu, J.U. and Van den Ban, A.W. (2000). Agricultural research-extension linkage systems: an international perspective. Agricultural Research and Extension Network Paper No. 106.

3. Agbamu, J.U (2006). Essential of Agricultural Communication in Nigeria. Lagos: Malthouse Press Limited.

4. Boyd, D. M., \& Ellison, N. B. (2007). Social network sites: Definition, history, and scholarship. Journal of ComputerMediated Communication, 13, 210-230.

5. Christofides, E., Muise, A. and Desmarais, S. (2008) "Information Disclosure and Control on Facebook: Are They Two Sides of the Same Coin or Two Different Processes?" CyberPsychology and Behaviour12(2) 341-345

6. CIARD(Coherence Information for Agricultural Research and Development) (2009) "Using Social Media to Communicate Research Outputs." Version 0.1 October 2009

7. Dwyer,C., Hiltz, S. R and Passerini, K. 2007. "Trust and privacy concern within social networking sites: A comparison of Facebook and MySpace”. In Proceedings of AMCIS 2007, Keystone, Colarado, USA, 2007. Retrieved October $2^{\text {nd }}, 2017$ from http://csis.pace.edu/ dwyer/research/DwyerAMCIS2007.pdf

8. FMARD (2011): “Agricultural Transformation Agenda” Nigeria: Report on Agricultural Extension Transformation” Federal Ministry of Agriculture and Rural development, Abuja. Research Enugu: New Generation Books.

9. Ibrahim, A. (2011): Climate change mitigation adopted by cassava farmers in oyo state, Nigeria. Pp.2-9.

10. Mayfield, A. (2008). What is social media? iCrossing. Retrieved October 2, 2017, from www.icrossing.co.uk/.../What_is_Social_Media_iCrossing_ebook.pdf

11. Pew Research Center (November 2, 2005). Teen content creators and consumers. Retrieved March 15, 2010, from http://www.pewinternet.org/Reports/2005/Teen-ContentCreators-and-Consumers.aspx

12. Pew Research Center (January, 2009). Adults and social network websites. Retrieved March 14, 2010, from http://www.pewinternet.org/Reports/2009/Adults-and-SocialNetwork-Websites/1-Summary-of-findings/One-third-of-

American-adult-internetusers-have-a-profile-on-an-online-social-network-site.aspx?r=1

13. Raacke, J., \& Bonds-Raacke, J. (2008). MySpace and Facebook: Applying the uses and gratifications theory to exploring friend-networking sites. Cyberpsychology\& Behavior, 11(2), 169-174. 
14. Sokoya, A.A, Onifade, F.N and Alabi, A.O. (2012) Establishing connection and Networking; The Role of Social Media in Agricultural Research in Nigeria. World Library and Information Congress.http://conference.ifla.org/ifla 78 Retrieve 2nd October, 2017 